\title{
PRODUCTION OF BACTERIOCIN-LIKE SUBSTANCES BY LACTIC ACID BACTERIA ISOLATED FROM REGIONAL OVINE CHEESE
}

\author{
Cássia Regina Nespolo; Adriano Brandelli*
}

Laboratório de Bioquímica e Microbiologia Aplicada, Instituto de Ciência e Tecnologia de Alimentos, Universidade Federal do Rio Grande do Sul, Porto Alegre, RS, Brasil

Submitted: June 24, 2009; Returned to authors for corrections: February 18, 2010; Approved: June 21, 2010.

\begin{abstract}
Lactic acid bacteria (LAB) were isolated from ovine milk and cheeses manufactured in the South Region of Brazil. Among 112 bacterial isolates investigated, 59 were chosen through a screening for LAB. Among these 59 strains of LAB, 21\% showed antimicrobial, proteolytic and lipolytic activities. Based on this screening, Lactobacillus plantarum LCN 17 and Lactobacillus rhamnosus LCN 43 were selected and tested for the production of bacteriocin-like substances (BLS). The BLS produced by both isolates showed antimicrobial activity against Listeria monocytogenes, whereas that produced by L. plantarum LCN 17 presented higher stability to different temperature, $\mathrm{pH}$ and enzyme treatments. These strains present potential for production of BLS, and for use as starter cultures.
\end{abstract}

Key words: lactic acid bacteria; bacteriocin-like substances; ewe's raw milk; Brazilian ovine cheese

\section{INTRODUCTION}

A broad group of microorganisms eventually gain access to the curd from the cheese-making environment, and will consequently contribute for the ripening process. Lactic acid bacteria (LAB) are largely predominant in such a microbial group, and are believed to play a key role in the characteristics of the final cheese. The products of LAB catabolism contribute, not only for preservation, but also to the flavor, aroma and texture, thereby helping to determine unique product characteristics (24). LAB are used as natural or selected starters in food fermentations, especially for the manufacture of dairy products with functional and probiotic properties. The indigenous microbial content of cheeses, which are selected by the raw milk and cheese-making environment and technology, could be considered one of the main factors in determining the typical cheese features $(3,8)$.
The starter cultures commonly used in cheese manufacture include Lactococcus, Leuconostoc Lactobacillus species and Streptococcus thermophilus. Although LAB are weakly proteolytic, they possess a very comprehensive proteinase/peptidase system capable of hydrolyzing oligopeptides to small peptides and amino acids (30). A comparison of starters and nonstarter LAB producing proteolytic and lipolytic enzymes showed that mesophilic lactobacilli have greater adaptation to cheese-like conditions. The relative abundance of certain species and, especially, the heterogeneity of nonstarter LAB strains in cheese may determine the relationships between these strains and cheese flavor (8). Technological characterization of LAB strains for preparation of the experimental starter could include, in particular, growth, acidifying and proteolytic activity (19).

The ability to produce lactic acid from lactose is probably the most important property of dairy LAB. It helps to reduce 
$\mathrm{pH}$, which in turn increases the expulsion of whey from the curd, thus lowering the moisture content (3). Protection of food from spoilage and pathogenic microorganisms by $\mathrm{LAB}$ is associated to production of organic acids, hydrogen peroxide, diacetyl, antifungal compounds, and bacteriocins $(11,27)$.

Numerous strains of LAB associated with food systems produce bacteriocins, defined as proteinaceous substances that exhibit bactericidal activity against closely related organisms $(2,22)$. Considering that bacteriocin-producing LAB are mostly isolated from foods like dairy and meat products, these antimicrobial substances have been consumed for a long time (23). Several bacteriocins from Gram-positive bacteria are very effective, have wide inhibitory spectra and may be used as antimicrobial agents in various practical applications $(9,34)$. An alternative approach to introduce bacteriocins is the use of live cultures, which will produce bacteriocins in situ in the food (22). The cultivation of LAB strains for inoculation purposes is in many ways relatively inexpensive and since various strains have a GRAS status, their addition to food should not have regulatory problems $(9,11)$.

Production of typical dairy products from ewes can provide a profitable alternative to cow milk products owing to their specific taste, texture and their natural and healthy properties (29). The production of the ewe's cheese is recent in Brazil and located in the southernmost region, for climatic and geographic reasons. The aim of this study was to isolate LAB from ovine milk and Fascal cheese, a typical Brazilian ovine cheese, and to determine the antimicrobial, proteolytic and lipolytic activities of the isolated strains.

\section{MATERIALS AND METHODS}

\section{Samples}

The LAB used in this study were isolated from raw ovine milk and from cheeses produced without the addition of starter cultures, obtained from a commercial cheese plant located in Viamão, Rio Grande do Sul, Brazil. Milk samples were collected from the refrigerated tank, before cheese production. This dairy farm produced a hard ewe's cheese, made from raw milk without the addition of lactic acid starters, in a cylindrical shape, with ripening time of up to 3 months. Cheeses were sampled after 1,30,60 and 90 days of ripening.

\section{Isolation of Lactic Acid Bacteria (LAB)}

Samples ( $25 \mathrm{~mL}$ or $25 \mathrm{~g}$ ) were diluted in $225 \mathrm{~mL}$ of sterile saline $\left(9 \mathrm{~g} \mathrm{~L}^{-1} \mathrm{NaCl}\right)$ for $2 \mathrm{~min}$ in a blender (Stomacher 400, Seward). After filtering it through a sterile gauze, the homogenate was decimally diluted in sterile saline and selected dilutions were plated on MRS agar (Vetec) or M17 agar (Difco). Mesophilic lactobacilli were isolated after anaerobic incubation on MRS acidified to $\mathrm{pH} 5.5$, at $30^{\circ} \mathrm{C}$ for $72 \mathrm{~h}$. Coccal-shaped LAB were isolated on M17 agar incubated anaerobically at $30^{\circ} \mathrm{C}$ for $72 \mathrm{~h}$ in an anaerobic jar (Anaerocult $\mathrm{C}$ gas generator, Merck). Colony counts were done for all agar plates after incubation. At least 10 colonies, with possibly different morphologies, were isolated from the greatest plate dilutions. Working cultures were grown in appropriate (MRS or M17) broth media. Growth of the coccal-shaped bacteria was examined in M17 broth after incubation at $10^{\circ} \mathrm{C}$ for 7 days and at $45^{\circ} \mathrm{C}$ for 2 days, excluding those strains growing at $45^{\circ} \mathrm{C}(5)$. The organic acid production by the screened strains was determined by measuring the $\mathrm{pH}$. All isolates were tested for their Gram reaction, cell morphology, and catalase reaction. The LAB selection was carried out by the exclusion of those strains producing a $\mathrm{pH}$ above 5.0 in MRS or M17 broth medium, Gram-negative stain and catalase-positive reaction. Bacteria were maintained as stock cultures frozen at $-21{ }^{\circ} \mathrm{C}$ in $15 \%(\mathrm{v} / \mathrm{v})$ glycerol. Strains were propagated twice before used in experiments.

\section{Proteolytic and Lipolytic Activities}

All selected isolates were tested for the production of proteolytic or lipolytic activity by agar diffusion assays at $22^{\circ} \mathrm{C}$ for $72 \mathrm{~h}$ and $120 \mathrm{~h}$, respectively. Proteolytic activity was tested using $1 \%(\mathrm{w} / \mathrm{v})$ skim milk agar. The presence of clear zones around the colonies, after using $1 \%(\mathrm{v} / \mathrm{v}) \mathrm{HCl}$ for $1 \mathrm{~min}$, was indicative of proteolysis (20). Lipolytic activity was evaluated in tributyrin agar plates. Colonies surrounded by clear zones 
were deemed to present lipolytic activity (20).

\section{Antibacterial Activity}

The antibacterial activity was initially tested against Listeria monocytogenes ATCC 7466 by agar disk diffusion assay (21). Aliquots of 24-h culture media were centrifuged at $10,000 \mathrm{~g}$ for $10 \mathrm{~min}$, at $4^{\circ} \mathrm{C}$. Supernatants were filtered through $0.22 \mu \mathrm{m}$ membranes (Millipore) and stored in sterile flasks at $4^{\circ} \mathrm{C}$, until use for antimicrobial assay. The resulting filtrates were used to evaluate antimicrobial activity. An aliquot of 20 $\mu \mathrm{L}$ cell-free culture supernatant was applied on cellulose disks $(6 \mathrm{~mm})$ on BHI agar plates (Difco) previously inoculated with a swab submerged in a L. monocytogenes suspension, which corresponded to a $0.5 \mathrm{McFarland}$ turbidity standard solution. Plates were incubated aerobically at $37^{\circ} \mathrm{C}$ for $24 \mathrm{~h}$, and the diameters of the inhibition zones around the disks were measured.

After performing proteolytic, lipolytic and antibacterial trials, isolates that presented positive results were selected to test their antimicrobial spectra. The antagonistic activity was detected against 23 indicator strains (Table 1). Cell-free culture supernatants, obtained as described above, were spotted in triplicate onto M17 and MRS agar. Plates were incubated anaerobically at $35^{\circ} \mathrm{C}$ for $24 \mathrm{~h}$, and then overlaid with $5 \mathrm{~mL}$ of Brain Heart Infusion (BHI) soft-agar $(0.7 \%$ agar) seeded with $0.1 \mathrm{~mL}$ of an overnight culture of the indicator strains. To exclude the effect of lactic acid, sodium- $\beta$-glycerophosphate (Merck) was incorporated to a final concentration of $2 \%(\mathrm{w} / \mathrm{v})$ in the overlay agar (28). Plates were incubated aerobically for additional $24 \mathrm{~h}$, and then checked for clear zones around spots, measured in millimeters. Sterile MRS broth was spotted as a control. Results considered positive when diameter of inhibition halo were $\geq 8 \mathrm{~mm}$ (28). To exclude the inhibition due to the presence of lytic bacteriophages, one piece of agar from the inhibition zone observed in the antimicrobial assay was cut and tested according to Lewus et al. (18).

\section{Identification of Selected LAB}

The selected strains were further identified and characterized by API 50CHL (BioMérieux), as recommended by the manufacturer. The APILAB Plus software (BioMérieux) was used to analyze the fermentation profiles obtained with the identification strips.

\section{Production of Crude Bacteriocin-like Substances (BLS)}

Selected cultures were grown in $250 \mathrm{~mL}$ Erlenmeyer flasks containing $100 \mathrm{~mL}$ of MRS broth incubated for $48 \mathrm{~h}$ at $30^{\circ} \mathrm{C}$ in a shaker at $125 \mathrm{rpm}$. Production of BLS was determined at $4 \mathrm{~h}$ intervals for $48 \mathrm{~h}$, and tested for cell-free culture aliquot, following the spot-on-lawn method. Aliquots of culture media were centrifuged at $10,000 \mathrm{~g}$ for $10 \mathrm{~min}$, at $4^{\circ} \mathrm{C}$. Correction of the cell-free supernatant to $\mathrm{pH} 6.0$ with a $1 \mathrm{M}$ $\mathrm{NaOH}$ solution prevented the inhibitory effect of organic acids. Supernatants were filtered through $0.22 \mu \mathrm{m}$ membranes (Millipore), and stored in sterile flasks at $4^{\circ} \mathrm{C}$ for up to $72 \mathrm{~h}$, until the antimicrobial assay took place. The resulting filtrates were used to evaluate antimicrobial activity.

\section{BLS Activity Assay}

For a semiquantitative assay of BLS, two fold serial dilutions of the supernatant were tested, using $L$. monocytogenes ATCC 7466 as indicator strain. The antibacterial activity was detected on plates by agar disk diffusion assay, as previously described. Plates were incubated aerobically at $35^{\circ} \mathrm{C}$ for $24 \mathrm{~h}$. The diameters of the inhibition zones around the disks were measured. The activity of BLS was defined as the reciprocal of the highest dilution yielding a zone of growth inhibition, and expressed as activity units (AU) per mL (21).

\section{Growth Determination}

Bacterial growth was developed at $30^{\circ} \mathrm{C}$ in a rotary shaker. At $8 \mathrm{~h}$ intervals, an aliquot of the bacterial suspension was diluted to $10^{-8}$ in sterile saline. Samples were homogenized and then loaded $(20 \mu \mathrm{L})$ in triplicate onto nutrient agar plates. Plates were incubated for 3 days at $30^{\circ} \mathrm{C}$, and counts proceeded, to determinate the number of viable cells.

\section{Susceptibility to $\mathrm{pH}$, temperature, and enzymes}

The effect of enzymes, temperature, and $\mathrm{pH}$ on BLS 
activity was determined as described elsewhere (1). Cell-free culture supernatants of isolates LCN 17 and LCN 43 with pH adjusted to 6.0 with a sterile $1 \mathrm{M} \mathrm{NaOH}$ solution were used. Proteolytic enzymes tested were trypsin (Sigma) and proteinase

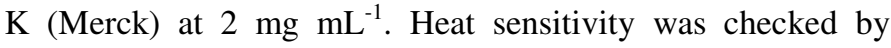
heating supernatants at $25^{\circ} \mathrm{C}, 37^{\circ} \mathrm{C}$, and $60^{\circ} \mathrm{C}$ for $60 \mathrm{~min}$, $100^{\circ} \mathrm{C}$ for $20 \mathrm{~min}$, autoclaving $\left(121^{\circ} \mathrm{C}\right.$ for $\left.15 \mathrm{~min}\right)$, and frozen for 30 days. Samples were incubated at different $\mathrm{pH}$ values $(\mathrm{pH}$ 2-11) and evaluated for residual activity (24). After the treatments, samples were filtered through $0.22 \mu \mathrm{m}$ membranes (Millipore) and tested for antimicrobial activity against $L$. monocytogenes ATCC 7644.

\section{Statistical analysis}

ANOVA was used to assess the effects of ripening time (1, 30, 60, 90 days) on viable counts of LAB in cheeses. Treatment comparisons were performed using Student-Newman-Keuls test and the values were considered significantly different each other at $P<0.05$.

\section{RESULTS AND DISCUSSION}

High counts of lactic acid bacteria were found during the whole ripening time in the tested cheese. The total number of $\mathrm{LAB}$ in samples of ovine cheese increased from $6.0 \log \mathrm{CFUg}^{-1}$ after production to $6.7 \log \mathrm{CFU} \mathrm{g}^{-1}$ after 60 days of ripening. Significant differences between the cheese samples that had ripened for 60 and for 90 days were not observed (Fig. 1a). The counts of LAB were lower than those observed for ewe cheeses produced in Portugal and Spain (10) and in Pecorino Sardo cheese (19). Presumptive mesophilic lactobacilli quantified at the end of ripening of nine Italian ewes' milk cheeses varied from 3.2 to $8.27 \log \mathrm{CFU} \mathrm{g}^{-1}$ (4).

One hundred and twelve strains were selected from samples of ovine milk and unpasteurised ewe's milk cheese during ripening (Fig. 1b). The strains from each sample were: 24 (ovine milk), 24 ( 1 d cheeses), 24 (30 d-ripened cheeses), 20 (60 d-ripened cheeses) and 20 (90 d-ripened cheeses).

Among the 112 isolates selected from the MRS and the
M17 culture media, 59 strains showed Gram-positive and catalase-negative results. Thirty isolates $(51 \%)$ of these LAB strains presented proteolytic activity (Fig. 1b). Proteolysis is important in affecting the basic taste of cheese, but its role may be more related to the provision of the substrates for enzymes involved in amino acid catabolism, which are often rate limiting for flavor formation. The proteolytic system of LAB includes a cell envelope-associated proteinase, transport systems for amino acids and peptides, and a number of intracellular proteinases and peptidases (25). Lactococcus lactis spp. lactis showed greater proteolytic activity in skim milk than Lactobacillus casei, but such activity was very low in Lactobacillus plantarum isolated from traditional Majorero cheese, manufactured with caprine milk (10). The two wild strains of L. lactis and Lactobacillus brevis investigated were similar in terms of proteolytic patterns in cheese, and they clearly improved release of free amino acids upon incorporation in cheesemaking milk (24).

The selected LAB showing lipolytic activity corresponded to $32 \%$ (19 isolates) (Fig. 1b). LAB are generally acknowledged as being weakly lipolytic and their lipases display substrate specificity, which is both strain and species dependent (20). During cheese ripening, starter lactococci and lactobacilli or secondary adventitious bacterial microbiota may cause a moderate accumulation of short- and long-chain free fatty acids, presumably by hydrolysis of either triacylglycerols or especially of the partial acylglycerols present in milk (16). Not all strains isolated from ewe's milk and cheeses that showed esterase activity exhibited high activity on triglycerides. The L. plantarum $\mathrm{O} 236$ and L. plantarum $\mathrm{O} 186$ strains were able to hydrolyze tributyrin, whereas L. lactis O233, L. plantarum O155, and Lactobacillus casei O190 did not hydrolyze triglycerides (17). The criteria for the selection of adjunct cultures used in cheese production are often not defined, and frequently isolates from a good-quality cheese have been selected for evaluation. However, there is a need to identify the proteolytic and lipolytic enzyme systems of the nonstarter LAB that could potentially contribute for the overall maturation process (30). LAB lipases and esterases appear to 
be the main lipolytic agents in Cheddar and Dutch-type cheeses, and some authors concluded towards the existence of preliminary evidence for a relationship between autolysis of starter bacteria and lipolysis in cheese (6).

The results of the antibacterial test against $L$. monocytogenes are shown in Fig. 1b. Antilisterial activity was observed in $39 \%$ (23 isolates) of the selected LAB. These results are very similar to those found for isolates selected during the ripening of Alentejo's traditional cheeses, for which $39.2 \%$ revealed antilisterial activity (14). The effect of isolates against L. monocytogenes is very important for the dairy industry, as this pathogen was isolated from cheeses manufactured with raw milk, ripened cheeses, and in the wash water employed for cheese production (13). (a)

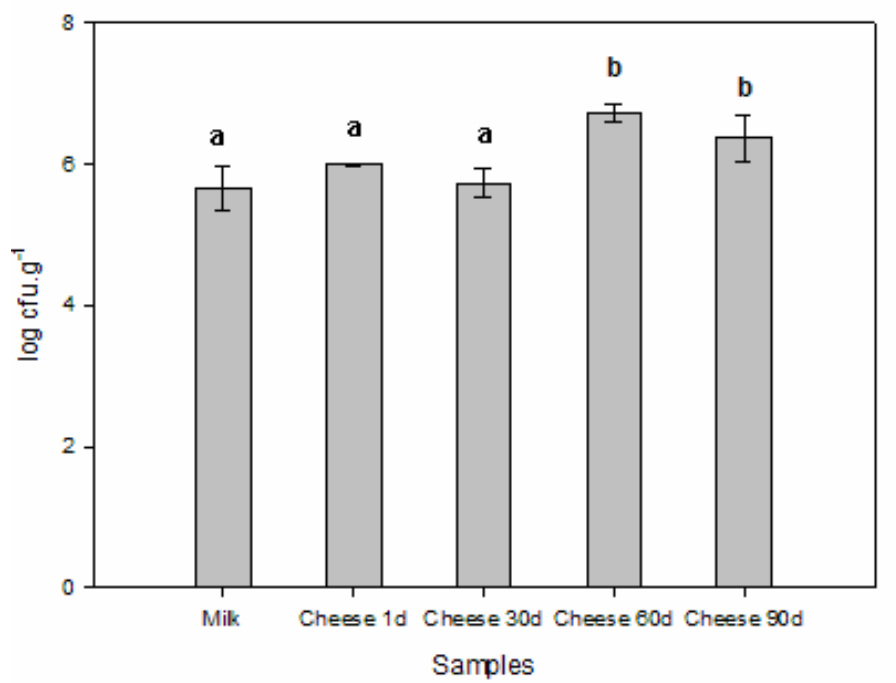

(b)

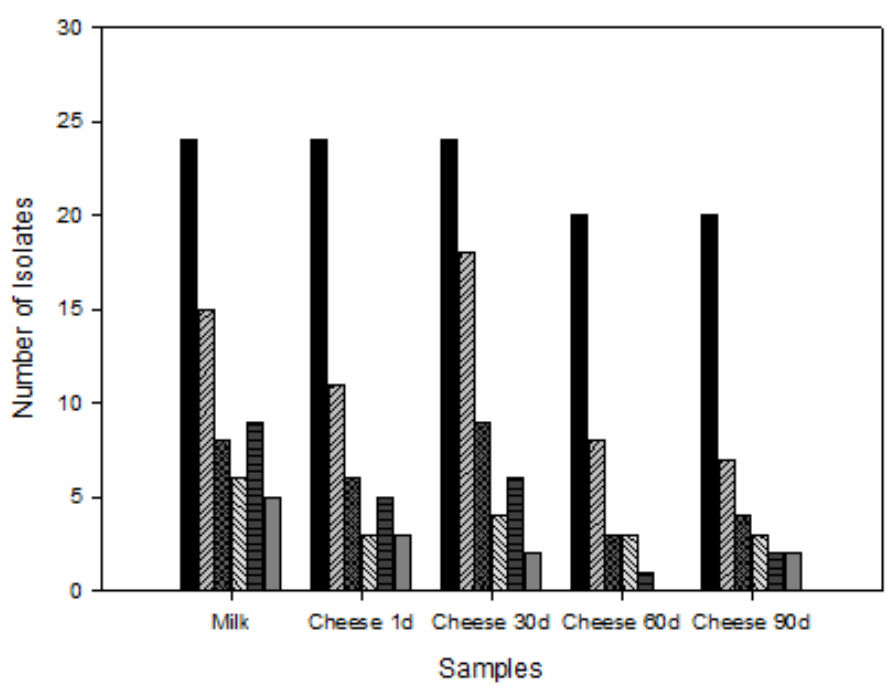

Figure 1. Isolation and selection of lactic acid bacteria (LAB) from Brazilian ovine cheese. (a) Viable counts of LAB in ovine milk and during the cheese ripening. Means with different letters are significantly different $(P<0.05)$. (b) Selection of bacterial isolates from ovine milk and during the cheese ripening: isolates selected from MRS and M17 plates (ם); Gram-positive and

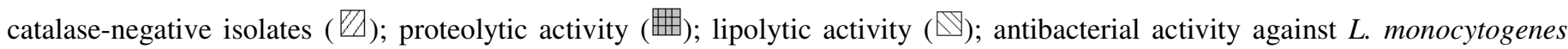
ATCC $7644(\boxminus)$; proteolytic, lipolytic and antibacterial activity $(\square)$. Values are the means \pm SE of three determinations of three different cheese from a same lot.

Isolated LAB showing lipolytic, proteolytic, and antibacterial activities achieved 21\% (12 isolates) (Fig. 1b). Three isolates showed similar activities and the largest clear zones around the colonies. The sensitivity of 23 bacterial strains from different genera to the LCN 17, LCN 20, and LCN 43 isolates is presented in Table 1. Results demonstrate that all isolates presented antimicrobial activity against both Grampositive and Gram-negative bacteria, and against spoilage and pathogenic bacteria. Previously, antimicrobial activity against microorganisms involved in mastitis and other diseases of sheep flock was also reported $(7,26,35)$. As shown in Table 1, crude supernatants of LCN 17 and LCN 43 demonstrated similar spectra of activity, broader than that produced by the isolate LCN 20.

The isolates showed antimicrobial activity against Escherichia coli, a bacterium already found in ewe cheeses 
such as Serra da Estrela, Serpa (10) and Pecorino del Poro (3). Caridi et al. (3) observed higher counts of E. coli at the beginning of the ripening period. However, this bacterium could not be detected by the end of ripening. This fact could be explained by the presence of bacteriocin-producing bacteria in the raw ovine milk used for cheese manufacture. Antimicrobial activity of isolates against Salmonella Enteritidis was observed, but not against Salmonella Gallinarum (Table 1).

Similar results were observed against indicator strains of Staphylococcus aureus and Clostridium perfringens, for all selected isolates (Table 1). The inhibitory effect by indigenous LAB of Fascal cheese is important, since S. aureus and
Clostridium spp. have been described as common contaminants of dairy products and were detected in ovine milk samples and cheeses produced in Iberian Peninsule and France $(10,13,35)$. On the other hand, antimicrobial activity against Enterococcus faecalis was not observed (Table 1). Enterococci were found in artisanal cheeses produced with sheep, goat, buffalo and cow pasteurized or raw milk, and E. faecalis and Enterococcus faecium were the most frequently species detected in cheeses (12). Similar absence of activity was observed against Pseudomonas aeruginosa. However, all isolates presented antimicrobial activity against Pseudomonas fluorescens, a microorganism detected in Serra da Estrela cheese curd (10).

Table 1. Antimicrobial spectrum of lactic acid bacteria isolated from Brazilian ovine cheese.

\begin{tabular}{|c|c|c|c|}
\hline \multirow[b]{2}{*}{ Indicator Strain ${ }^{\text {a }}$} & \multicolumn{3}{|c|}{ Inhibition zone (mm) ${ }^{b}$} \\
\hline & LCN 17 & LCN 20 & LCN 43 \\
\hline Bacillus cereus ATCC 9634 & $9.0 \pm 0.5$ & $5.0 \pm 0.0$ & $5.8 \pm 0.3$ \\
\hline Bacillus subtilis (food isolate) & $6.8 \pm 0.3$ & $6.3 \pm 0.3$ & $7.3 \pm 0.3$ \\
\hline Brevibacterium linens ATCC 9172 & $10.3 \pm 0.3$ & $5.5 \pm 0.5$ & $11.0 \pm 0.5$ \\
\hline Clostridium perfringens type B & $5.8 \pm 0.3$ & $6.0 \pm 0.0$ & $6.8 \pm 0.3$ \\
\hline Corynebacterium fimi NCTC 7547 & $10.0 \pm 0.0$ & $4.3 \pm 0.3$ & $9.3 \pm 0.3$ \\
\hline Enterobacter aerogenes (food isolate) & $8.8 \pm 0.3$ & $6.0 \pm 0.0$ & $8.3 \pm 0.3$ \\
\hline Enterococcus faecalis (food isolate) & - & - & - \\
\hline Escherichia coli ATCC 25922 & $8.0 \pm 0.0$ & $8.3 \pm 0.3$ & $9.5 \pm 0.5$ \\
\hline Lactobacillus acidophilus ATCC 4356 & $8.3 \pm 0.3$ & $5.8 \pm 0.3$ & $10.3 \pm 0.3$ \\
\hline Leuconostoc mesenteroides & $4.3 \pm 0.3$ & $3.5 \pm 0.5$ & $4.5 \pm 0.5$ \\
\hline Listeria innocua (food isolate) & $11.5 \pm 0.5$ & $8.3 \pm 0.3$ & $10.3 \pm 0.3$ \\
\hline Listeria monocytogenes ATCC 7644 & $10.5 \pm 0.5$ & $6.5 \pm 0.5$ & $10.0 \pm 0.0$ \\
\hline Listeria seeligeri AC 8214 & $9.3 \pm 0.3$ & $4.5 \pm 0.5$ & $10.5 \pm 0.5$ \\
\hline Pseudomonas aeruginosa ATCC & - & - & - \\
\hline Pseudomonas fluorescens (clinical isolate) & $8.3 \pm 0.3$ & $8.0 \pm 0.0$ & $8.3 \pm 0.3$ \\
\hline Salmonella enteritidis ATCC 13076 & $9.3 \pm 0.3$ & $8.3 \pm 0.3$ & $8.3 \pm 0.3$ \\
\hline Salmonella gallinarum (clinical isolate) & - & - & - \\
\hline Staphylococcus aureus (food isolate) & $8.8 \pm 0.3$ & $8.3 \pm 0.3$ & $8.5 \pm 0.5$ \\
\hline Staphylococcus aureus ATCC 25923 & $8.3 \pm 0.3$ & $8.0 \pm 0.0$ & $8.3 \pm 0.3$ \\
\hline Staphylococcus haemolyticus (clinical isolate) & $10.5 \pm 0.5$ & $6.3 \pm 0.3$ & $11.5 \pm 0.5$ \\
\hline Staphylococcus intermedius (clinical isolate) & $6.0 \pm 0.5$ & $8.0 \pm 0.0$ & $6.8 \pm 0.3$ \\
\hline Streptococcus agalactiae (clinical isolate) & $6.5 \pm 0.5$ & - & $7.3 \pm 0.3$ \\
\hline Streptococcus pneumoniae (clinical isolate) & $11.3 \pm 0.3$ & - & $12.3 \pm 0.3$ \\
\hline
\end{tabular}

${ }^{\mathrm{a}}$ Indicator strains were grown on BHI agar plates for $24 \mathrm{~h}$; ${ }^{\mathrm{b}}$ zone of growth inhibition $\geq 8 \mathrm{~mm}$ was considered as positive, lack of inhibition zone as negative (-), and a weak inhibition when the diameter was $<8 \mathrm{~mm}$. Values are the means $\pm \mathrm{SE}$ of three independent determinations. 
The isolates were identified with API 50CHL system and classified as L. plantarum (LCN 17), Lactococcus sp. (LCN 20), and L. rhamnosus (LCN 43). Nevertheless, L. rhamnosus was not considered as an usual LAB in ewe's cheeses (10). Non-starter LAB were isolated from Italian ewe cheeses, produced by different manufacturers. Phenotypically, the cheese isolates included $32 \% \mathrm{~L}$. plantarum isolates and $1 \% \mathrm{~L}$. rhamnosus isolates (8). L. plantarum and L. paracasei were the species found most frequently in Pecorino cheeses, with 56 and 29 isolates over the total of 99 isolates (4). Several strains of bacteriocin-producing $L$. plantarum have been isolated from different dairy products, including Cabrales cheese, crude goat's milk and fermented milk (31,32).

Strains LCN 17 and LCN 43 were selected for BLS production during a $48 \mathrm{~h}$ period. Viable cell counts, $\mathrm{pH}$ and antibacterial activity were monitored during cultivation (Fig. 2). Exponential cell growth reached the stationary phase after $36 \mathrm{~h}$ of cultivation. The $\mathrm{pH}$ decreased during cultivation, reaching values around 3.0 (Fig. 2 b). The activity against $L$. monocytogenes ATCC 7644 was detected from 16 hours of BLS production. The maximum values were observed from 32 hours for both isolates (Fig. 2c). Maximum BLS production was $6400 \mathrm{AU} \mathrm{mL}{ }^{-1}$, for both LCN 17 and LCN 43 isolates, which was not coincident with minimum $\mathrm{pH}$ values. (a)

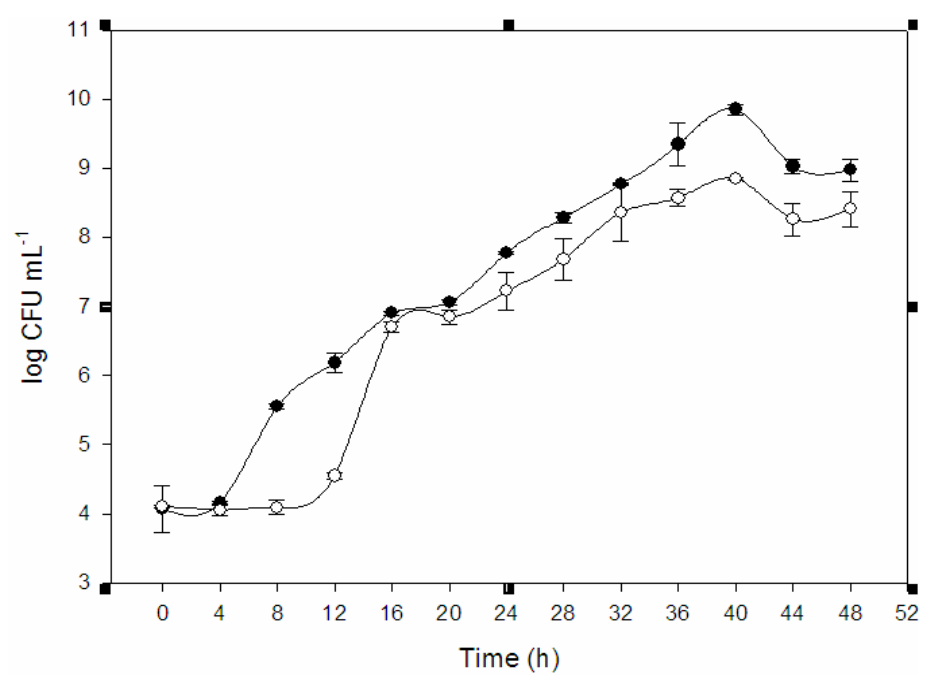

(c)

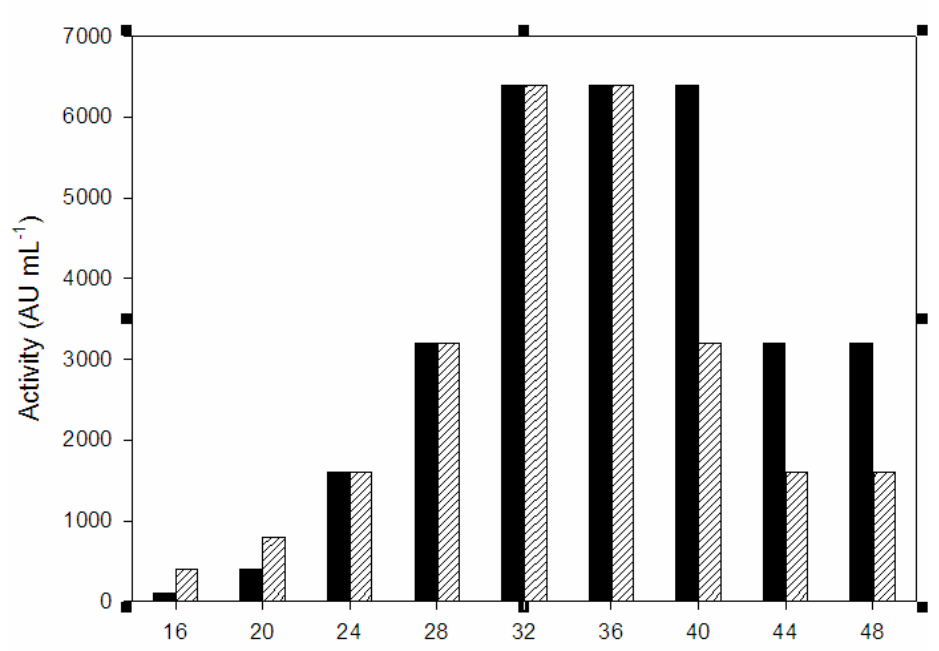

(b)

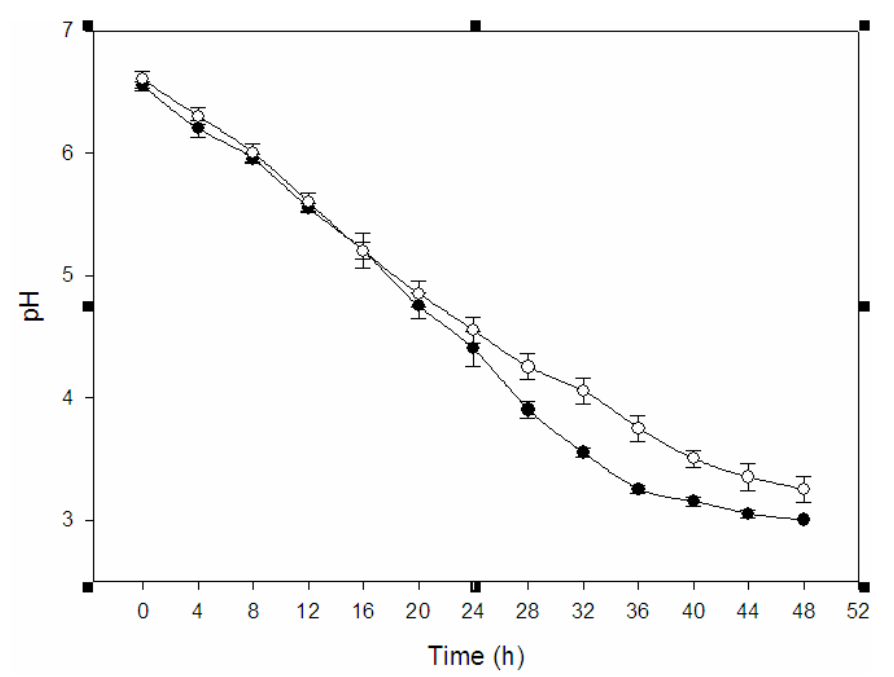

Figure 2. Production of antimicrobial activity against Listeria monocytogenes, during growth of selected lactic acid bacteria. Strains LCN $17(\bullet)$ and LCN 43 (O) were grown in MRS broth and monitored for viable cell counts (a), pH (b), and antibacterial activity (c). In panel (c), LCN 17 (ם) and LCN 43 ( $/$ ). Values are the means \pm SE of three independent determinations. 
The cell free supernatant (6400 $\left.\mathrm{AU} \mathrm{mL} \mathrm{mL}^{-1}\right)$ were incubated at various temperatures and at different $\mathrm{pH}$ values. The antibacterial activity was measured against L. monocytogenes and results are expressed as the percentage of residual activity (Table 2). Both compounds were sensitive to trypsin and proteinase $\mathrm{K}$, indicating that activity was associated to the production of a bacteriocin-like substance. LCN 43 was more sensitive to the different temperature or $\mathrm{pH}$ treatments. BLS produced by LCN 17 or LCN 43 isolates were stable for up to $60^{\circ} \mathrm{C}$ for $60 \mathrm{~min}$, and BLS produced by LCN 17 remained stable after freezing for 30 days. The treatment at $100^{\circ} \mathrm{C}$ for 20 min presented the same effects on the antibacterial activity for both BLS, with $47 \%$ of residual activity. After autoclaving, BLS produced by LCN 17 showed greater residual activity than that observed for the other sample. Similarly, no decrease in antibacterial activity was reported after $90 \mathrm{~min}$ at $100^{\circ} \mathrm{C}$ or $20 \mathrm{~min}$ at $121^{\circ} \mathrm{C}$ for bacteriocins produced by L. plantarum (33). L. plantarum isolated from Turkish dairy products showed antibacterial activity due to BLS. The substances were resistant to heat and the inhibitory activity was not lost after 10 and $20 \mathrm{~min}$ at $100^{\circ} \mathrm{C}(23)$.

Table 2. Stability of BLS after different treatments.

\begin{tabular}{lcc}
\hline & Residual Activity (\%) & \\
\cline { 2 - 3 } Treatment & LCN 17 & LCN 43 \\
\hline Temperature & & $100 \pm 0$ \\
$25^{\circ} \mathrm{C} / 60 \mathrm{~min}$ & $100 \pm 0$ & $100 \pm 0$ \\
$37^{\circ} \mathrm{C} / 60 \mathrm{~min}$ & $100 \pm 0$ & $100 \pm 0$ \\
$60^{\circ} \mathrm{C} / 60 \mathrm{~min}$ & $100 \pm 0$ & $47 \pm 0$ \\
$100^{\circ} \mathrm{C} / 20 \mathrm{~min}$ & $47 \pm 0$ & $8 \pm 0$ \\
$121^{\circ} \mathrm{C} / 15 \mathrm{~min} / 15 \mathrm{lb} \mathrm{in}^{-2}$ & $15 \pm 6$ & $74 \pm 26$ \\
$-20^{\circ} \mathrm{C} / 30$ days & $100 \pm 0$ & \\
$\mathrm{pH}$ & & $74 \pm 16$ \\
2 & $34 \pm 13$ & $100 \pm 0$ \\
4 & $100 \pm 0$ & $100 \pm 0$ \\
5 & $100 \pm 0$ & $100 \pm 0$ \\
7 & $100 \pm 0$ & $74 \pm 26$ \\
9 & $100 \pm 0$ & $15 \pm 6$ \\
11 & $34 \pm 13$ & $42 \pm 8$ \\
Enzymes & & $0 \pm 0$ \\
Trypsin & $83 \pm 12$ & \\
\hline Vateinase K & $6 \pm 0$ & \\
\hline
\end{tabular}

Values are the means \pm SE of three independent determinations.

The effect of $\mathrm{pH}$ on stability of BLS was investigated for both isolates, at $\mathrm{pH}$ values from 2.0 to 11.0. Results demonstrated that BLS produced by LCN 43 had lower stability to the variations of $\mathrm{pH}$, including values of $\mathrm{pH}$ 9.0. At pH 2.0 and 11.0, BLS produced both by LCN 17 and 43 lost part of the antibacterial activity. Oppositely, bacteriocins ST28MS and ST26MS, produced by L. plantarum remained stable after incubation for $2 \mathrm{~h}$ at $\mathrm{pH}$ values between 2.0 and 12.0, without reduction of the antimicrobial activity (33). L. plantarum TF711 isolated from raw Tenerife goat's cheese 
produced a bacteriocin-like substance, which was called plantaricin TF711. This substance was stable to heat and highest antimicrobial activity was found between $\mathrm{pH} 1$ and 9 $(15,23)$.

BLS produced by Lactobacillus plantarum LCN 17 and Lactobacillus rhamnosus LCN 43, isolated from ovine cheese showed antimicrobial activity against Listeria monocytogenes, and stability to different temperature, $\mathrm{pH}$ and enzyme treatments was higher for those produced by L. plantarum LCN 17. Moreover, L. rhamnosus LCN 43 and L. plantarum LCN 17 showed proteolytic and lipolytic activities, indicating potential for use as starter cultures.

\section{ACKNOWLEDGEMENTS}

The authors thank Conselho Nacional de Desenvolvimento Científico e Tecnológico (CNPq) and Coordenação de Aperfeiçoamento de Pessoal de Nível Superior (CAPES) for financial support.

\section{REFERENCES}

1. Bizani, D.; Brandelli, A. (2002). Characterization of a bacteriocin produced by a newly isolated Bacillus sp. strain 8A. J. Appl. Microbiol. 93, 512-519.

2. Bromberg, R.; Moreno, I.; Zaganini, C.L.; Delboni, R.R.; Oliveira, J. (2004). Isolation of bacteriocin-producing lactic acid bacteria from meat and meat products and its spectrum of inhibitory activity. Braz. J. Microbiol. 35, 137-144.

3. Caridi, A. (2003). Identification and first characterization of lactic acid bacteria isolated from de artisanal ovine cheese Pecorino del Poro. Int. J. Dairy Technol. 56, 105-110.

4. Coda, R.; Brechany, E.; De Angelis, M.; De Candia, S.; Di Cagno, R.; Gobbetti, M. (2006). Comparison of the compositional, microbiological, biochemical, and volatile profile characteristics of nine Italian ewes' milk cheeses. J. Dairy Sci. 89, 4126-4143.

5. Cogan, T.M.; Barbosa, M.; Beuvier, E.; Bianchi-Salvadori, B.; Cocconcelli, P.S.; Fernandes, I.; Gomez, J.; Gomez, R.; Kalantzopoulos, G.; Ledda, A.; Medina, M.; Rea, M.C.; Rodriguez, E. (1997). Characterization of the lactic acid bacteria in artisanal dairy products. $J$. Dairy Res. 64, 409-421.

6. Collins, Y.F.; McSweeney, P.L.H.; Wilkinson, M.G. (2003). Lipolysis and free fatty acid catabolism in cheese: a review of current knowledge. Int. Dairy J. 13, 841-866.
7. Contreras, A.; Sierra, D.; Sánchez, A.; Corrales, J.C.; Marco, J.C.; Paape, M.J.; Gonzalo, C. (2007). Mastitis in small ruminants. Small Rum. Res. $68,145-153$

8. De Angelis, M.; Corsetti, A.; Tosti, N.; Rossi, J.; Corbo, M.R.; Gobbetti, M. (2001). Characterization of non-starter lactic acid bacteria from Italian ewe cheeses based on phenotypic, genotypic, and cell wall protein analyses. Appl. Environ. Microbiol. 67, 2011-2020.

9. De Martinis, E.C.P.; Alves, V.F.; Franco, B.D.G.M. (2002) Fundamentals and perspectives for the use of bacteriocins produced by lactic acid bacteria in meat products. Food Rev. Int. 18, 191-208.

10. Freitas, C.; Malcata, F.X. (2000). Microbiology and biochemistry of cheeses with Appélation d'Origine Protegeé and manufactured in the Iberian Peninsula from ovine and caprine milks. J. Dairy Sci. 83, 584602 .

11. Gálvez, A.; Abriouel, H.; López, R.L.; Omar, N.B. (2007). Bacteriocinbased strategies for food biopreservation. Int. J. Food Microbiol. 120, 5170.

12. Gelsomino, R.; Vancanneyet, M.; Cogan, T.M.; Condon, S.; Swings, J. (2002). Source of enterococci in a farmhouse raw-milk cheese. Appl. Environ. Microbiol. 68, 3560-3565.

13. Glass, K.; Doyle, M.E. (2005). Safety of Processed Cheese: A Review of the Scientific Literature. Food Research Institute, Madyson, pp. 1-11.

14. Guerra, M.M.M.; Bernardo, F.M.A. (2001). Characterization of the inhibitors effects of L. monocytogenes Scott A produced by ripening microflora of Alentejo's traditional cheeses. Rev. Port. Cienc. Vet. 96, 65-69.

15. Hernández, D.; Cardell, E.; Zárate, V. (2005). Antimicrobial activity of lactic acid bacteria isolated from Tenerife cheese: initial characterization of plantaricin TF711, a bacteriocin-like substance produced by Lactobacillus plantarum TF711. J. Appl. Microbiol. 99, 77-84.

16. Holland, R.; Coolbear, T. (1996). Purification of tributyrin esterase from Lactococcus lactis subsp. cremoris E8. J. Dairy Res. 63, 131-140.

17. Katz, M.; Medina, R.; Gonzalez, S.; Oliver. G. (2002). Esterolytic and lipolytic activities of lactic acid bacteria from ewe's milk and cheese. $J$. Food Prot. 65, 1997-2001.

18. Lewus, C.B.; Kaiser, A.; Montville, T.J. (1991). Inhibition of food-borne bacterial pathogens by bacteriocins from lactic acid bacteria isolated from meat. Appl. Environ. Microbiol. 57, 1683-1688.

19. Madrau, M.A.; Mangia, N.P.; Murgia, M.A.; Sanna, M.G.; Garau, G.; Leccis, L.; Caredda, M.; Deiana, P. (2006). Employment of autochthonous microflora in Pecorino Sardo cheese manufacturing and evolution of physicochemical parameters during ripening. Int. Dairy J. $16,876-885$.

20. MAPA. Ministério da Agricultura, Pecuária e Abastecimento, Brasil. (2003). Instrução Normativa $N^{\circ}$. 62 de 26/08/2003. Oficializa os Métodos Analíticos Oficiais para Análises Microbiológicas para Controle de Produtos de Origem Animal e Água. D.O.U., Brasília, 18/09/2003. 14 p.

21. Motta, A.S.; Brandelli, A. (2002). Characterization of an antibacterial peptide produced by Brevibacterium linens. J. Appl. Microbiol. 92, 63- 
70.

22. O'Sullivan, L.; Ross, R.P.; Hill, C. (2002). Potential of bacteriocinproducing lactic acid bacteria for improvements in food safety and quality. Biochimie. 84, 593-604.

23. Parada, J.L.; Caron, C.R.; Medeiros, A.B.P.; Soccol, C.R. (2007). Bacteriocins from lactic acid bacteria: purification, properties and use as biopreservatives. Braz. Arch. Biol. Tech. 50, 521-542.

24. Pereira, C.I.; Gomes, E.O.; Gomes, A.M.P.; Malcata, F.X. (2008) Proteolysis in model Portuguese cheeses: effects of rennet and starter culture. Food Chem. 108, 862-868.

25. Piraino, P.; Zotta, T.; Ricciardia, A.; McSweeney, P.L.H.; Parente, E. (2008). Acid production, proteolysis, autolytic and inhibitory properties of lactic acid bacteria isolated from pasta filata cheeses: A multivariate screening study. Int. Dairy J. 18, 81-92.

26. Raynal-Ljutovac, K.; Pirisi, A.; Crémoux, R.; Gonzalo, C. (2007). Somatic cells of goat and sheep milk: Analytical, sanitary, productive and technological aspects. Small Rum. Res. 68, 126-144.

27. Rodríguez, E.; González, B.; Gaya, P.; Nuñez, M.; Medina, M. (2000). Diversity of bacteriocins produced by lactic acid bacteria isolated from raw milk. Int. Dairy J. 10, 7-15.

28. Schillinger, U.; Lucke, F. (1989). Antibacterial activity of Lactobacillus sake isolated from meat. Appl. Environ. Microbiol. 55, 1901-1906.
29. Scintu, M.F.; Piredda, G. (2007). Typicity and biodiversity of goat and sheep milk products. Small Rum. Res. 68, 221-231.

30. Sousa, M.J.; Ardö, Y.; McSweeney, P.L.H. (2001). Advances in the study of proteolysis during cheese ripening. Int. Dairy J. 11, 327-345.

31. Torodov, S.D. (2008). Bacteriocin production by Lactobacillus plantarum AMA-K isolated from Amasi, a Zimbabwean fermented milk product and study of the adsorption of bacteriocin AMA-K to Listeria sp. Braz. J. Microbiol. 39, 178-187.

32. Torodov, S.D. (2009). Bacteriocins from Lactobacillus plantarum production, genetic organization and mode of action. Braz. J. Microbiol. 40, 209-221.

33. Torodov, S.D.; Dicks, L.M.T. (2005). Lactobacillus plantarum isolated from molasses produces bacteriocins active against Gram-negative bacteria. Enzyme Microb. Technol. 36, 318-326.

34. Torodov, S.D.; Dicks, L.M.T. (2007). Bacteriocin production by Lactobacillus pentosus ST712BZ isolated from boza. Braz. J. Microbiol. 38, 166-172.

35. Vautor, E.; Abadie, G.; Guibert, J.M.; Huard, C.; Pépin, M. (2003). Genotyping of Staphylococcus aureus isolated from various sites on farms with dairy sheep using pulsed-field gel electrophoresis. Vet. Microbiol. 96, 69-79. 